\title{
PERBEDAAN KADAR KOLESTEROL LDL DARAH TIKUS SPRAGUE DAWLEY PADA PEMBERIAN KOPI FILTER DAN TANPA FILTER
}

\author{
Raysa Tanjung Sari, Niken Puruhita*) \\ Program Studi Ilmu Gizi Fakultas Kedokteran Universitas Diponegoro \\ Jl.Dr.Sutomo No.14, Semarang, Telp (024) 8453708, Email : gizifk@undip.ac.id
}

\begin{abstract}
Background : Coffee contains cafestol and kahweol which can increase LDL cholesterol levels. Effect of cafestol and kahweol with chlorogenic acids are antagonist in coffee. Chlorogenic acids is strong antioxidant in coffee. Unfiltered coffee contains more chlorogenic acids and cafestol than filtered coffee. The study aims to determine the differences of LDL cholesterol levels of Sprague Dawley rats in giving filtered and unfiltered coffee.

Methods : a laboratory experimental study, with randomized pre-post test control group design, with a simple random sampling to 28 Sprague Dawley rats were divided into 3 groups. The first treatment was given unfiltered coffee $4 \times 2.7 \mathrm{ml}$, the second treatment was given filtered coffee $4 \times 2.7 \mathrm{ml}$ and the control was given water $4 \times 2.7 \mathrm{ml}$ for 28 days. LDL cholesterol levels were determined by the homogenous enzyme method. Data were analyzed by paired $t$-test and Oneway ANOVA test at $95 \%$ confident level.

Results : Changes levels of LDL cholesterol in filtered coffee $(0.85 \mathrm{mg} / \mathrm{dl})$ are higher than unfiltered coffee $(0.15$ $\mathrm{mg} / \mathrm{dl})$. However statistical test shows there is no significant difference of $L D L$ cholesterol in filtered and unfiltered coffee $(p>0.05)$.

Conclusion: There is no significant difference of LDL cholesterol levels of Sprague Dawley rats in filtered and unfiltered coffee
\end{abstract}

Key words : unfiltered coffee; filtered coffee; LDL cholesterol; Sprague Dawley rats

\section{ABSTRAK}

Latar Belakang : Kopi mengandung kafestol dan kahweol yang dapat meningkatkan kadar kolesterol LDL. Efek kafestol dan kahweol antagonis dengan asam klorogenat dalam kopi. Asam klorogenat merupakan antioksidan kuat dalam kopi. Kopi tanpa filter mengandung asam klorogenat dan kafestol lebih besar daripada kopi filter. Penelitian ini bertujuan untuk mengetahui perbedaan kadar kolesterol LDL darah tikus Sprague Dawley pada pemberian kopi filter dan tanpa filter.

Metode : merupakan penelitian eksperimental laboratorik, dengan randomized pre-post test control group design, dilakukan dengan rancangan acak sederhana terhadap 28 ekor tikus Sprague Dawley yang dibagi dalam 3 kelompok. Kelompok perlakuan 1 diberi kopi tanpa filter $4 \times 2.7 \mathrm{ml}$, kelompok perlakuan 2 diberi kopi filter $4 \times 2.7 \mathrm{ml}$ dan kelompok kontrol diberi air putih $4 \times 2.7 \mathrm{ml}$ selama 28 hari. Kadar kolesterol LDL ditentukan dengan metode homogenous enzyme. Data dianalisis dengan uji paired t-test dan oneway Anova pada tingkat kepercayaan 95\%.

Hasil : Perubahan kadar kolesterol LDL pada kopi filter $(0.85 \mathrm{mg} / \mathrm{dl})$ lebih tinggi daripada kopi tanpa filter $(0.15$ mg/dl). Namun uji statistik menunjukkan tidak ada perbedaan kadar kolesterol LDL secara bermakna pada kopi filter dan tanpa filter $(p>0.05)$.

Simpulan : Tidak ada perbedaan kadar kolesterol LDL tikus Sprague Dawley secara bermakna pada pemberian kopi filter dan tanpa filter.

Kata kunci : kopi tanpa filter; kopi filter; kolesterol LDL; tikus Sprague Dawley

\section{PENDAHULUAN}

Dislipidemia adalah kelainan metabolisme lipid yang ditandai dengan peningkatan maupun penurunan fraksi lipid dalam darah. Kelainan fraksi lipid ini dapat berupa peningkatan kadar kolesterol total, LDL (Low Density Lipoprotein), trigliserida darah, dan penurunan HDL (High Density Lipoprotein). ${ }^{1}$ Berdasarkan data Badan Kesehatan Dunia pada tahun 2011, sebesar $35,1 \%$ penduduk
Indonesia mengalami peningkatan kadar kolesterol darah. $^{2}$

Peningkatan kolesterol darah terutama LDL kolesterol dalam jangka waktu lama meyebabkan terjadinya penimbunan lemak di dalam lapisan pembuluh darah yang membentuk plak kolesterol. Plak kolesterol mengakibatkan terjadinya pengerasan dan penyempitan pembuluh darah sehingga suplai darah ke otot jantung berkurang yang menyebabkan penyakit jantung.

${ }^{*}$ Penulis Penanggungjawab 
Faktor yang berkaitan dengan kadar kolesterol LDL antara lain genetik, jenis kelamin, usia, gaya hidup, dan pola diet sehari-hari. ${ }^{3-5}$ Pola diet yang salah yaitu kecenderungan konsumsi makananan rendah serat dan tinggi lemak. ${ }^{6}$

Kopi merupakan minuman yang digemari oleh masyarakat di dunia karena aroma dan mutu yang nikmat. ${ }^{7}$ Kopi mengandung asam klorogenat yang dapat menurunkan kadar kolesterol LDL dengan cara menghambat lipolisis trigliserida. Asam klorogenat merupakan antiokasidan kuat di dalam kopi. ${ }^{8}$ Sementara itu, kopi juga memiliki efek negatif yaitu dapat meningkatkan risiko penyakit jantung. ${ }^{9}$ Hal tersebut diduga karena kopi mengandung senyawa kafestol dan kahwoel. ${ }^{9,10}$ Kedua senyawa ini merupakan diterpen yang dapat meningkatkan kadar kolesterol total, LDL, trigliserida, dan alanina aminotranferase. ${ }^{11}$

Perbedaan kandungan kafestol dan kahwoel dalam kopi tergantung dari jenis kopi dan proses filtrasi. Kopi Arabika mengandung kafestol dan kahwoel sedangkan kopi Robusta terutama mengandung kafestol. ${ }^{11}$ Kopi tanpa filter mengandung kafestol 6-12 mg/cangkir sedangkan kopi filter hanya mengandung $0.2-0.6$ $\mathrm{mg} /$ cangkir. $^{12}$ Berdasarkan penelitian yang telah dilakukan, konsumsi kopi tanpa filter sebanyak 900 $\mathrm{ml}$ per hari meningkatkan kadar trigliserida darah sebesar $31 \%$ atau $0.32 \mathrm{mmol} / \mathrm{L} .{ }^{10}$ Sementara itu, penelitian yang lain menunjukkan bahwa konsumsi kopi filter sebanyak $600 \mathrm{ml}(\approx 4$ cangkir) selama 4 minggu dapat meningkatkan kolesterol total 0.15 $0.25 \mathrm{mmol} / \mathrm{l} .{ }^{13} \mathrm{Hal}$ ini terjadi karena kafestol dan kahwoel tersaring pada kertas saring dengan diameter pori-pori $5 \mu \mathrm{m} .^{14}$

Penelitian mengenai pengaruh kadar kolesterol LDL pada kopi filter dan kopi tanpa filter masih kontroversi. Di samping itu, belum ditemukan penelitian yang secara langsung membandingkan kedua jenis kopi ini. Secara khusus penelitian ini bertujuan untuk menganalisis perbedaan perubahan kadar kolesterol LDL pada tikus Sprague Dawley dengan pemberian kopi filter dan tanpa filter.

\section{METODE PENELITIAN}

Penelitian ini merupakan penelitian eksperimental laboratorik, dengan randomized prepost test control group design. Variabel bebas dalam penelitian ini adalah jenis pemrosesan kopi, dengan pemberian jenis kopi filter dan tanpa filter pada tikus dan variabel terikat adalah perubahan kadar kolesterol LDL darah tikus selama perlakuan.
Penelitian ini berlangsung selama 35 hari dilakukan di Laboratorium Layanan Penelitian Pra Klinik dan Pengembangan Hewan Percobaan Jurusan Biologi, FMIPA Universitas Semarang. Sampel yang digunakan adalah 30 ekor tikus jantan Sprague Dawley berumur 8 minggu, kondisi sehat dan berat badan normal $(150-200$ gr). Proses aklimatisasi dilakukan selama 7 hari dengan menggunakan kandang individu dan mendapat pakan standar BR 2 sebanyak 15 g/hari serta minum ad libitum.

Tikus selanjutnya dibagi menjadi 3 kelompok masing-masing 10 ekor yang ditentukan menurut rumus besar sampel ekperimental Federer, yaitu (n-1) (t-1) $\geq 15$. Pengelompokkan tikus ditentukan secara acak sederhana dengan memberi nomer pada kandang tikus kemudian pengambilan nomor melalui lotere. Selanjutnya dilakukan pemeriksaan kadar LDL kolesterol awal.

Selama 28 hari masing-masing kelompok diberi pakan standar BR 2 dan air minum ad libitum dengan 3 jenis perlakuan yang berbeda, yaitu kelompok kontrol (P0) dengan pemberian air putih $4 \times 2.7 \mathrm{ml}$, kelompok perlakuan 1 (P1) dengan pemberian kopi tanpa filter $4 \times 2.7 \mathrm{ml}$ dan kelompok perlakuan 2 (P2) dengan pemberian kopi filter $4 \times 2.7 \mathrm{ml}$

Kopi yang digunakan dalam penelitian ini adalah biji kopi robusta merek "X" yang dihaluskan dengan mesin penggiling kopi menjadi bubuk kopi. Larutan kopi dibuat dari $1.8 \mathrm{~g}$ bubuk kopi yang dilarutkan ke dalam $27 \mathrm{ml}$ air panas. Kopi diaduk rata dan didiamkan beberapa saat sampai ampas kopi mengendap. Pada kopi filter dilakukan proses filtrasi dengan kertas saring kopi sehingga menjadi larutan kopi tanpa ampas. Setelah masa perlakuan 28 hari maka dilakukan pemeriksaan kadar LDL kolesterol akhir. Sebelum dilakukan pemeriksaan darah, tikus dipuasakan selama 12 jam. Kadar LDL kolesterol ditentukan dengan metode direct yaitu pemeriksaan dengan homogeneous enzym.

Data yang diperoleh diolah dengan program komputer. Data tersebut diuji normalitas dengan uji Saphiro-Wilk. Perbedaan kadar kolesterol LDL sebelum dan sesudah perlakuan diuji dengan paired t-test. Perbedaan pengaruh dari ketiga kelompok perlakuan dianalisis dengan uji Oneway ANOVA.

\section{HASIL PENELITIAN \\ Karakteristik Sampel}

Tiga puluh tikus Sprague Dawley berjenis kelamin jantan dipelihara dalam kandang 
individual. Dua ekor tikus mati saat perlakuan sehingga digunakan dua puluh delapan ekor tikus selama perlakuan berlangsung. Pertumbuhan berat badan tikus dimonitor dengan penimbangan yang dilakukan setiap tiga hari. Demikian pula setiap hari dilakukan penimbangan sisa pakan untuk mengetahui konsumsi pakan per hari. Hal tersebut dapat dilihat pada tabel 1 dan 2 .

Tabel 1. Rerata dan Simpang Baku Berat Badan Sebelum dan Sesudah Perlakuan

\begin{tabular}{|c|c|c|c|c|}
\hline \multirow[t]{2}{*}{ Perlakuan } & \multicolumn{2}{|c|}{ Berat Badan (g) } & \multirow[t]{2}{*}{$\Delta(\mathbf{g})$} & \multirow[t]{2}{*}{ p value } \\
\hline & Sebelum & Sesudah & & \\
\hline P0 & $161.3 \pm 5.2$ & $200.2 \pm 13.1$ & 38.9 & \\
\hline P1 & $181.9 \pm 9.9$ & $238.8 \pm 23.5$ & 56.9 & 0.043 \\
\hline $\mathrm{P} 2$ & $185.7 \pm 14,1$ & $236.7 \pm 23.7$ & 51.0 & \\
\hline
\end{tabular}

Berdasarkan uji Oneway ANOVA menunjukkan ada perbedaan perubahan berat badan secara signifikan antara P0 dengan P1 dan P0 dengan P2 ( $<<0.05)$. Perubahan berat badan terendah terdapat pada kelompok P0 sebesar 38.9 g. Pola pertumbuhan tikus selama perlakuan dapat terlihat pada grafik 1.

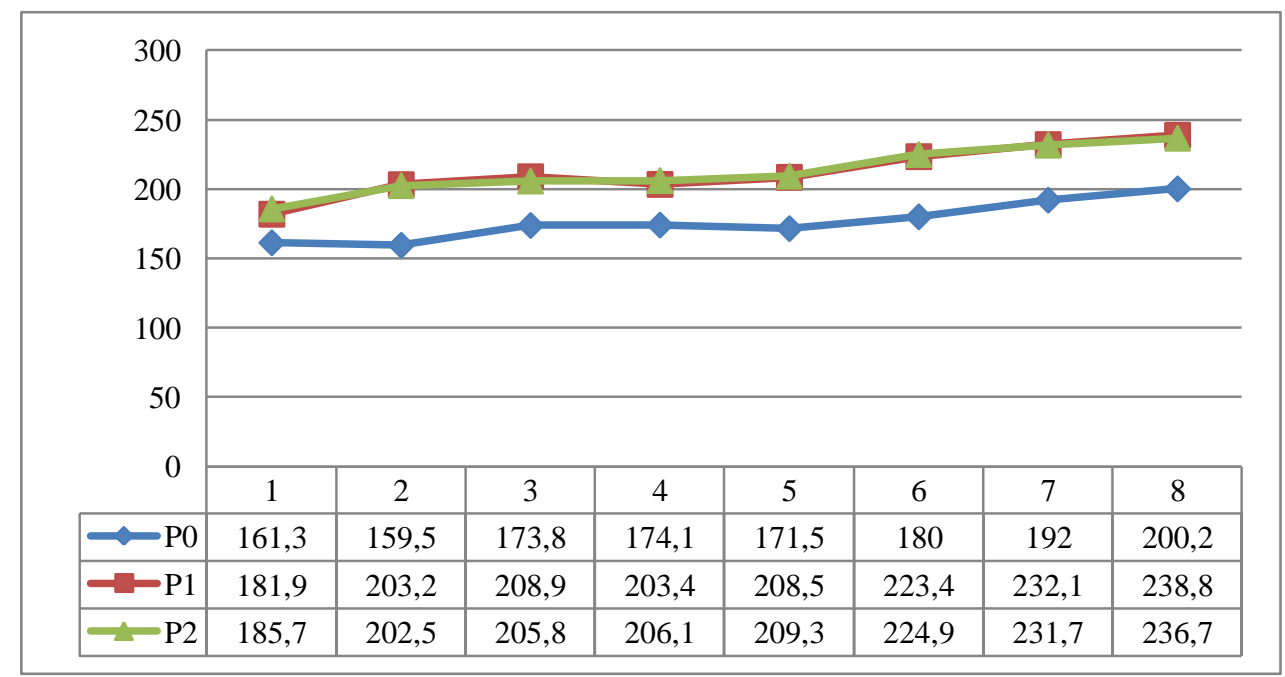

Grafik 1. Pola Pertumbuhan Tikus Selama Perlakuan

Pada semua kelompok terjadi penambahan penambahan berat badan pada kelompok P0 berada berat badan tikus secara bertahap tetapi di bawah garis pertumbuhan $\mathrm{P} 1$ dan $\mathrm{P}$.

Tabel 2. Rerata dan Simpang Baku Asupan Pakan Harian Sebelum dan Selama Perlakuan

\begin{tabular}{|c|c|c|c|c|}
\hline \multirow[t]{2}{*}{ Perlakuan } & \multicolumn{2}{|c|}{ Asupan Pakan Harian (g/hari) } & \multirow[t]{2}{*}{$\Delta$ (g/hari) } & \multirow[t]{2}{*}{$p$ value } \\
\hline & Sebelum & Selama & & \\
\hline P0 & $16.4 \pm 1,6$ & $12.9 \pm 1,9$ & -3.5 & 0.02 \\
\hline $\mathrm{P} 1$ & $18.1 \pm 1,7$ & $15.5 \pm 1,6$ & -2.6 & 0.014 \\
\hline $\mathrm{P} 2$ & $18.1 \pm 1,1$ & $15.3 \pm 1,9$ & -2.8 & 0.001 \\
\hline
\end{tabular}

Berdasarkan tabel 2, terlihat ada perbedaan asupan pakan sebelum dan sesudah perlakuan pada setiap kelompok $(\mathrm{p}<0.05)$. Pada semua kelompok terjadi penurunan asupan pakan, terutama pada kelompok P0 yang menurun sebanyak 3.5 g/hari. Selama perlakuan, urutan rerata asupan pakan tertinggi terdapat pada kelompok P1 (15.5 g/hari), P1 (15.3 g/hari) dan P0 (12.9 g/hari). Hasil uji
Oneway ANOVA menunjukkan tidak terdapat perbedaan asupan pakan antara ketiga kelompok perlakuan ( $\mathrm{p}>0.05)$.

Kolesterol LDL sebelum dan sesudah pemberian Kopi

Berdasarkan hasil penelitian, didapatkan gambaran rerata kadar kolesterol LDL sebelum dan sesudah perlakuan yang disajikan dalam Tabel 3 . 
Tabel 3. Perbedaan Rerata dan Simpang Baku Kadar LDL Sebelum dan Sesudah Perlakuan

\begin{tabular}{ccccc}
\hline Perlakuan & \multicolumn{2}{c}{ Kadar LDL $(\mathbf{m g} / \mathbf{d l})$} & $\Delta(\mathbf{m g} / \mathbf{d l})$ & $\boldsymbol{p}$ value \\
\cline { 2 - 3 } & Sebelum & Sesudah & & \\
\hline P0 & $9.7 \pm 2.9$ & $11.5 \pm 2.6$ & 1.8 & 0.274 \\
P1 & $11.0 \pm 4.1$ & $11.2 \pm 3.6$ & 0.2 & 0.114 \\
P2 & $10.9 \pm 3.4$ & $11.7 \pm 2.5$ & 0.8 & 0.112 \\
\hline
\end{tabular}

Uji paired t-test menunjukkan tidak terdapat perbedaan kadar kolesterol LDL secara bermakna sebelum dan sesudah perlakuan pada setiap kelompok ( $\mathrm{p}>0.05)$. Peningkatan kadar kolesterol LDL secara berturut-turut yaitu 1,8 $\mathrm{mg} / \mathrm{dl}(\mathrm{P} 0), 0.8 \mathrm{mg} / \mathrm{dl}(\mathrm{P} 2)$ dan $0.2 \mathrm{mg} / \mathrm{dl}(\mathrm{P} 1)$. Berdasarkan hasil uji Oneway ANOVA, menunjukkan tidak terdapat perbedaan kadar kolesterol LDL secara signifikan antara ketiga kelompok perlakuan $(\mathrm{p}>0.05)$

\section{PEMBAHASAN}

\section{Perubahan Kadar Kolesterol LDL}

Hasil penelitian menunjukkan terjadi peningkatan kadar kolesterol LDL yaitu $1,8 \mathrm{mg} / \mathrm{dl}$

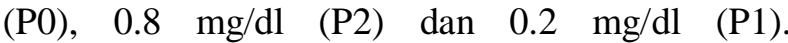
Peningkatan pada kelompok P0 (kontrol) lebih tinggi daripada P1 dan P2. Peningkatan kadar kolesterol LDL pada kelompok P0 (kontrol) karena rerata asupan pakan yang rendah selama penelitian yaitu 12,9 g/hari. Asupan pakan yang semakin rendah selama penelitian diduga menyebabkan lipolisis tahap awal pada kelompok kontrol.

Lipolisis terjadi dalam jaringan adiposa karena terjadi penurunan cadangan glukosa untuk menghasilkan energi. Pada kondisi ini, tubuh akan meningkatkan lipolisis sehingga akan terjadi peningkatan asam lemak bebas dalam darah. Asam lemak bebas masuk ke dalam hati dan teroksidasi membentuk trigliserida. Trigliserida dan ester kolesterol diangkut keluar dari hati oleh VLDL menuju jaringan ekstrahepatik. Trigliserida dalam VLDL akan dipecah oleh lipoprotein lipase menjadi asam lemak yang akan ditangkap oleh reseptor VLDL pada jaringan ekstrahepatik. VLDL yang kehilangan sebagian besar trigliserida akan berubah menjadi LDL yang kaya kolesterol. Dengan demikian, peningkatan lipolisis pada kelompok P0 akan memicu peningkatan asam lemak bebas yang dapat meningkatkan sintesis LDL dalam darah. ${ }^{15,16}$

Asupan pakan yang rendah pada kelompok P0 mengakibatkan penambahan berat badan yang tidak optimal yaitu 38.9 g selama 4 minggu. Penambahan berat badan tersebut di bawah laju pertumbuhan kelompok P1 dan P2 yang ditunjukkan dengan adanya perbedaan perubahan berat badan antara kelompok P0 (38.9 g) dengan P1 (56.9 g) dan P0 dengan P2 (51.0 g).

\section{Perbedaan Kadar Kolesterol LDL pada Kopi Filter dan Tanpa Filter}

Bedasarkan uji statistik, menunjukkan tidak terdapat perbedaan kadar kolesterol LDL secara bermakna pada pemberian kopi filter dan tanpa filter. Perubahan kadar kolesterol LDL yaitu, kopi filter $(0.8 \mathrm{mg} / \mathrm{dl})$ dan kopi tanpa filter $(0.2$ $\mathrm{mg} / \mathrm{dl}$ ). Hasil ini menunjukkan bahwa kopi filter lebih meningkatkan kadar kolesterol LDL daripada kopi tanpa filter.

Hasil penelitian tersebut kontras dengan penelitian yang dilakukan oleh Sanders dan Sandaradura, dimana konsumsi kopi tanpa filter mampu meningkatkan kadar LDL sebesar 15.2 $\mathrm{mg} / \mathrm{dl} .{ }^{17}$ Namun hasil penelitian yang dipublikasikan pada British Journal of Nutrition, menyebutkan bahwa kopi tanpa filter tidak berpengaruh signifikan dalam meningkatkan kadar kolesterol LDL pada tikus wistar. ${ }^{18}$

Pada penelitian ini, pemberian kopi fiter dan tanpa filter tidak meningkatkan kadar LDL secara signifikan diduga karena adanya efek positif dari asam klorogenat yang merupakan antioksidan terbanyak dalam kopi. Asam klorogenat dibentuk dari caffeic acid dan quinic acid yang merupakan antioksidan kuat secara in vitro. Bioavailabiltas asam klorogenat sangat tinggi sehingga dengan cepat diabsorbsi dan dimetabolisme oleh tubuh. ${ }^{19}$ Konsumsi kopi pada manusia dapat meningkatkan antioksidan dalam plasma. ${ }^{20}$ Pada studi penelitian yang dilakukan oleh Yukawa et al, menyebutkan bahwa konsumsi kopi selama 7 hari dapat menurunkan oksidasi LDL dan kadar lipid pada manusia. ${ }^{21}$

Asam klorogenat dapat menurunkan kadar kolesterol LDL dengan cara menghambat lipolisis trigliserida di jaringan adiposa sehingga mengurangi transpor asam lemak bebas ke hati. Penurunan asam lemak bebas ini akan mengurangi sintesis trigliserida di dalam hati yang menyebabkan penurunan sintesis VLDL ke 
jaringan ekstrahepatik sehingga kadar LDL dalam darah menurun. ${ }^{8}$

Hasil penelitian menunjukkan bahwa kadar kolesterol LDL pada kopi tanpa filter lebih rendah daripada kopi filter. Hal tersebut diduga karena kandungan asam klorogenat pada kopi tanpa filter lebih besar ( $325 \mathrm{mg} /$ cangkir) dibandingkan dengan kopi filter (200 mg/cangkir) karena senyawa tersebut tidak tersaring pada kertas filtrasi. ${ }^{22}$

Sementara itu, kopi juga mengandung kafestol dan kahwoel yang dapat meningkatkan kadar kolesterol LDL darah. Kopi tanpa filter mengandung kafestol 6-12 mg/cangkir sedangkan kopi filter hanya mengandung $0.2-0.6$ $\mathrm{mg} /$ cangkir. ${ }^{12}$ Dengan demikian, kopi tanpa filter lebih besar meningkatkan kadar kolesterol LDL daripada kopi filter. Namun, kandungan asam klorogenat pada kopi jauh lebih besar daripada kandungan kafestol sehingga diduga efek positif dari asam klorogenat mampu menurunkan efek negatif dari kafestol.

Kopi juga mengandung niasin sebesar $1-$ $0.7 \%$ yang merupakan produk sampingan dari proses dekomposisi trigonelina. ${ }^{23,24}$ Niasin berfungsi membantu metabolisme trigliserida untuk menurunkan kadar kolesterol LDL dengan cara menghambat lipolisis trigliserida di jaringan adiposa, mengurangi pengambilan asam lemak bebas oleh hati dan meningkatkan pengeluaran kolesterol oleh hati melalui getah empedu. ${ }^{11,23}$

Kemampuan asam klorogenat dan niasin pada kopi dalam menurunkan kadar LDL antagonis dengan efek kafestol dan kahwoel dalam meningkatkan kadar kolesterol LDL. Hal ini diduga menjadi penyebab tidak terdapat peningkatan kolesterol LDL secara signifikan setelah pemberian kopi filter dan tanpa filter.

\section{KETERBATASAN PENELITIAN}

Keterbatasan dalam penelitian ini adalah tidak dilakukan uji kandungan kafestol, kahwoel, asam klorogenat, dan niasin dalam kopi sehingga tidak diketahui jumlah zat tersebut yang dapat mempengaruhi kadar kolesterol LDL. Laboratorium yang digunakan termasuk laboratorium pada umumnya sehingga validitas hasil pengukuran pada sampel darah hewan coba tikus harus dikaji ulang.

\section{SIMPULAN}

Tidak terdapat perbedaan kadar kolesterol LDL darah tikus Sprague Dawley secara bermakna pada pemberian kopi filter dan tanpa filter.

\section{SARAN}

Perlu dilakukan penelitian lebih lanjut mengenai pengaruh pemberian kopi filter dan tanpa filter dengan dilakukan uji kandungan kafestol, kahwoel, asam klorogenat dan niasin. Laboratorium yang digunakan merupakan laboratorium klinik khusus hewan percobaan yang kualitasnya sudah terstandar.

\section{DAFTAR PUSTAKA}

1. Marmot MG. Epidemiology of tryglicerides and coronary heart disease. Lancet 1993; 342: 781.

2. World Health Organization. Noncommunicable diseases country profiles 2011.[serial online]. [dikutip pada tanggal 30 Januari 2012]. Diunduh dari http://www.who.int/nmh/countries/idn_en.pdf

3. Anwar BT. Dislipidemia sebagai faktor resiko penyakit jantung koroner.[Artikel]. Fakultas Kedokteran Universitas Sumatera Utara. e-USU Repository. 2004

4. Hutter, Carolyn M, Mellisa A, Austin, and Steve E Humphires. Familial hypercholesterolemia, peripheral arterial disease and stroke: a huge minireview. American Journal of Epidemiology.2004; 160(5): 430-435

5. Luley Clause, Gunnar Ronquist, Wolfgabf Reutter, Valerie Paal, Hans Detchlev, Sabine Westphal, et al. Point of care testing of triglycerides, evalution of the accutrend triglycerides system. Clinical Chemistry. 2000; 46:287-291

6. Cahanar P dan Irwan Suhanda. Makanan sehat hidup sehat. Jakarta: Penerbit Buku Kompas. 2006

7. Asosiasi Eksportir dan Industri Kopi Indonesia. Laporan pasar kopi bulan februari 2012. Jakarta. 2012 [serial online] [dikutip pada tanggal 30 Maret 2012]. Diunduh dari : http://www.aeki-aice.org/ pdf

8. Shu-Yuan Li, Cui-Qing Chang, Fu-Ying Ma and Chang-Long Yu. Modulating effects of chlorogenic acid on lipids and glucose metabolism and expression of hepatic peroxisome proliferatoractivated receptor- $\alpha$ in golden hamsters fed on high fat diet. Biomedical and Environmental Sciences. Elsevier : April 2009

9. Natella F, Nardini M, Belelli F, and Scaccini C. Coffee drinking induces incorporation of phenolic acids into LDL and increases the resistance of LDL to ex vivo oxidation in humans1-3. Am J Clin Nutr 2007;86:604 -9

10. De Roos Baukje, Muriel J Casalake, Anton FH Stalenhoef, Dorothy Bedford, Pierre NM Demacker, Martijin B Katan, et al. The coffee diterpene cafestol increases plasma triacyglycerol by increasing the production rate of large VLDL apolipoprotein $\mathrm{B}$ in healthy normolipidemic subjects. Am J Clin Nutr 2001;73:45-52.

11. Yi-Fang Chu. Coffee: emerging health effects and disease prevention. Willey-BlackWell. 2012 
12. Christensen Benedicte, Anhild Mosdol, Lars Retterstol, Sverre Landaas, Dag S Thelle. Abstention from filtered coffee reduces the concentrations of plasma homocysteine and serum cholesterol - a randomized controlled trial1-3. Am J Clin Nutr 2001;74:302-7

13. Strandhagen E and Thelle DS. Filtered coffee raises serum cholesterol: results from a controlled study. European Journal of Clinical Nutrition (2003) 57, 1164-1168

14. Van Dusseldorp M, Katan MB, van Vliet T, Demacker PN, Stalenhoef AF. Cholesterol-raising factor from boiled coffee does not pass a paperfilter. Arterioscler Thromb 1991;11:586-93

15. Bender DA dan Mayes PA. Tinjauan umum metabolisme dan penyediaan bahan bakar metabolik. Dalam Murray RK, Granner DK dan Rodwell VW. Biokimia Harper edisi ke-27. Jakarta: Penerbit Buku Kedokteran EGC ; 2006

16. Botham MB dan Mayes PA. Pengangkutan dan penyimpanan lipid. Dalam Murray RK, Granner DK dan Rodwell VW. Biokimia Harper edisi ke27. Jakarta: Penerbit Buku Kedokteran EGC ; 2006

17. Sanders TAB and Sandaradura S. The cholesterolraising effect of coffee in the Syrian hamster. British Journal of Nutrition (1992) 68,431-434.
18. Beynen AC, Western-van der Wouw, de Roos B, Katan MB. Boiled coffee fails to raise serum cholesterol in hamsters and rats. British Journal of Nutrition (1996) 76, 755-764

19. Farah Adriana, Monteiro Mariana, Donangelo MC, and Lafay Sophie. Chlorogenic acids from green coffee extract are highly bioavailable in humans. The Journal of Nutrition. J. Nutr. 138: 2309-2315, 2008

20. Natella F, Nardini M, Giannetti I, Dattilo C, Scaccini C. Coffee drinking influences plasma antioxidant capacity in humans. J Agric Food Chem $2002 ; 50: 6211-6$.

21. Yukawa GS, Mune M, Otani H, et al. Effects of coffee consumption on oxidative susceptibility of low-density lipoproteins and serum lipid levels in humans. Biochemistry (Mosc) 2004;69:70-4

22. Nardini M, Cirillo E, Natella F, and Scaccini.C. Absorption of phenolic acids in humans after coffee consumption. J. Agric. Food Chem., 2002, 50 (20), pp 5735-5741

23. Rivera Joseph. A brief tour of coffee's chemical composition: everyday millions of people around the world begin their day religiously with a cup of coffee. Tea \& Coffee Trade Journal : Feb 1, 2009

24. Belitz H.D, Grosch W, Schieberle.P. Food chemistry 3rd revised edition. Springer.2004. 